\title{
Inter-relações entre a dívida pública e política monetária no Brasil: uma análise histórica *
}

\author{
Elohá Cabreira Brito ** \\ Eliane Cristina de Araújo *** \\ Elisangela Luzia Araujo ****
}

\begin{abstract}
Resumo
O presente artigo tem como objetivo discutir a conexão existente entre a política monetária e a dívida pública no Brasil, destacando as implicações daí decorrentes. Para isso, parte de uma retomada histórica do surgimento do mercado de títulos da dívida pública e das instituições responsáveis por seu gerenciamento. Posteriormente, são discutidos os dados relativos às variáveis ligadas à política monetária e à dívida pública entre 1999 a 2016. A partir da referida análise, observou-se a existência de uma conexão problemática entre duas políticas - monetária e fiscal - dada pela taxa Selic que é, ao mesmo tempo, instrumento de controle da inflação e taxa que remunera parcela expressiva da dívida pública. O trabalho conclui que esta vinculação reduz a eficácia das referidas políticas, requerendo ações como desvinculação da política monetária e da dívida pública, elevação do prazo e duração da dívida, mudança da sua composição e, particularmente, redução da taxa Selic.
\end{abstract}

Palavras-chave: Política monetária; Dívida pública, Economia brasileira.

\section{Abstract}

\section{The interrelation between public debt and monetary policy in Brazil: a historical review}

This paper aims to discuss the connection between monetary policy and public debt in Brazil, highlighting the consequences. To do so, it begins with a historical resumption of the emergence of the market for public debt and the institutions responsible for its management. This is followed by an analysis of the data on the variables related to monetary policy and public debt between 1999 and 2016. From this analysis, we observed the existence of a problematic connection between two policies - monetary and fiscal - given by the Selic rate, which is both an instrument to control the inflation and the rate that remunerates a significant portion of public debt. The paper concludes that this link reduces the effectiveness of these policies, requiring actions such as the untying of monetary policy and public debt, the increase in the term and duration of debt, the change in composition and, particularly, a reduction of the Selic rate.

Keywords: Monetary policy; Public debt, Brazilian economy.

JEL: E52, E63, E59.

\footnotetext{
*Artigo recebido em 21 de julho de 2015 e aprovado em 14 de agosto de 2018.

** Doutoranda do Programa de Pós-Graduação em Economia da Universidade Federal do Rio Grande do Sul (UFRGS), Porto Alegre, RS, Brasil. E-mail: eloha.cabreira@gmail.com.

**** Professora Adjunta do Departamento de Economia da Universidade Estadual de Maringá (UEM), Maringá, PR, Brasil. E-mail: elianedearaujo@gmail.com.

${ }^{* * * * *}$ Professora Adjunta do Departamento de Economia da Universidade Estadual de Maringá (UEM), Maringá, PR, Brasil. E-mail: elaraujo@uem.br.
} 


\section{Introdução}

Dentre os diversos impasses que afetam o desenvolvimento econômico brasileiro na atualidade, está a existência de uma vinculação entre a política monetária e o arcabouço desenvolvido para o gerenciamento da dívida pública no país. A natureza dessa conexão interfere nos mecanismos de transmissão da política monetária e, dada a diferença de objetivos e metas das políticas monetária e fiscal, tem-se um comprometimento dos seus resultados e da eficácia de ambas as políticas ${ }^{1}$.

A razão é que o instrumento utilizado para o controle dos níveis de preços, a taxa de juros básica da economia - a Selic - dentro do atual arcabouço para a condução da política monetária, dado pelo Regime de Metas de Inflação (RMI), deve ser elevada nos momentos em que a inflação ameaça situar-se acima da meta e vice-versa. Deste modo, o governo, ao realizar determinada política monetária, afeta também a política fiscal e, uma vez que a alteração da Selic altera o montante de juros da dívida indexada a ela, implica em maior (ou menor) esforço fiscal para se alcançar determinado superávit primário definido pelas autoridades econômicas.

Esta interconexão entre as políticas monetária e fiscal, no sentido mencionado, tem origem em um dado contexto histórico, notoriamente, em meados da década de 1960, quando era imprescindível ao país criar mecanismos de proteção contra a inflação, para o estímulo à poupança doméstica e ao desenvolvimento de um mercado de títulos públicos e privados no país. Naquele contexto específico, vários instrumentos foram desenvolvidos para garantir rentabilidade e liquidez aos detentores da dívida pública. Dentre as principais características estava a forte indexação, o curto prazo de maturação e grande rentabilidade dos títulos, características típicas de contexto de inflação elevada e de grandes incertezas que o país recorrentemente vivenciava, até por volta da década de 1990.

A realidade que deu origem às instituições para a dívida pública e seu gerenciamento no Brasil se modificou consideravelmente a partir de meados dos anos 1990, com a estabilização da inflação obtida com o Plano Real (1994). O referido plano logrou o retorno da inflação para a casa de um dígito, após várias tentativas de estabilização ocorridas desde os anos 1980. Ao fim dos anos de 1990, também foram criadas novas políticas/instituições, cujo propósito deveria ser a criação de um arcabouço para a condução das políticas macroeconômicas domésticas na busca pela estabilidade em longo prazo.

Focalizando a atenção na política monetária, o novo quadro teórico que a sustenta, desde meados de 1999, passou a ser baseado na estratégia do RMI, no qual a estabilidade de preços se constitui no principal objetivo de longo prazo da autoridade econômica. Neste modelo, seguido pela economia brasileira, é estipulada e anunciada publicamente uma meta de médio prazo para a inflação, utilizando-se a taxa básica de juros como o principal instrumento

(1) Dentre os autores que se debruçam sobre essa problemática estão: Modenesi (2008), Parreiras (2007), Marques (1997) e Chrystal et al. (1999). 
de controle dos preços, além de outros aspectos como a transparência dos objetivos, metas, instrumentos e resultados alcançados pela política monetária.

No que se refere à política fiscal, esta não é mais vista, dentro deste arcabouço, como um poderoso instrumento macroeconômico para a estabilização econômica, pelo que, postula que sua condução deve ser de forma passiva. Isto é, o país deve estabelecer e realizar metas de superávit primário (isto é, as arrecadações do governo devem ser superiores aos gastos, excluindo-se as despesas financeiras). Essa política, que vem sendo adotada no Brasil desde 1999, tem como principal objetivo conferir credibilidade aos agentes econômicos e manter a dívida interna em uma trajetória de estabilidade relativa ao longo do tempo.

São, portanto, distintas as metas perseguidas pela política fiscal e monetária. Enquanto a primeira compromete-se com a manutenção de um superávit primário - sinalizando a possibilidade de pagamento dos juros da dívida pública, e, portanto, garantindo a credibilidade da política fiscal - a segunda visa o controle do nível de preços da economia, de acordo com o estabelecido pelo $\mathrm{RMI}^{2}$.

Todavia, a conexão mencionada entre a política monetária e a dívida pública implica em diversos problemas. Ao remunerar os títulos da dívida pública, quando ocorre uma elevação da taxa básica de juros, por exemplo, tem-se o impacto negativo sobre a política fiscal, que deverá ser mais austera e gerar superávit primário maior, para fazer face ao maior pagamento de juros. Também o impacto das taxas de juros sobre a demanda agregada pode se tornar mais reduzido, se a taxa de juros maior, ao invés de reduzir, elevar a riqueza de seus detentores, impedindo uma queda mais acentuada do consumo e o correto funcionamento dos mecanismos de transmissão da política monetária. Isso, sem mencionar os efeitos decorrentes do diferencial de juros sobre o ingresso de capitais no país, que causam diversos efeitos indesejados, aumentando a vulnerabilidade da economia (Rocha et al., 2017; Arestis et al., 2009).

Tais fatos, reforçam características marcantes da economia brasileira, tais como a curta duração dos títulos e dos prazos médios da dívida pública, resultam em perda de eficácia da política monetária, contribuindo para manter a taxa de juros em patamares superiores aos que prevaleceriam em situações consideradas adequadas. Deste modo, a forma da gestão da dívida pública e a sua conexão com a política monetária, a duração e prazo médio de vencimento de títulos, podem comprometer a eficácia da política monetária e fiscal. Amaral e Oreiro (2008), Barbosa (2006), Carneiro e Wu (2005), Pires (2008) são alguns autores que se debruçam sobre essa temática acerca dos problemas e das consequências para a economia brasileira da vinculação entre as políticas fiscal e monetária.

No que se refere às consequências, estas podem ser observadas pela análise da evolução de alguns dos indicadores macroeconômicos domésticos. Como exemplo, têm-se os

(2) Vale notar, ainda, a existência de um terceiro elemento na política macroeconômica, que foi adotado no fim da década de 1990 - o sistema de taxas de câmbio flutuante - constituindo, assim, o "tripé" de políticas macroeconômicas que prosseguiu como o arcabouço para a condução da política econômica desde então. Confira Baer (2013). 
déficits nominais crescentes, a despeito do esforço fiscal para a realização de superávit primário; a mudança do perfil da dívida conforme a trajetória seguida pela taxa Selic, sobretudo, em períodos de crise nacional ou internacional. Além disso, também são notórias as alterações na trajetória da taxa de câmbio, influenciadas pelo movimento da taxa básica de juros, que implicam na perda de competitividade doméstica e no aumento da vulnerabilidade externa, dentre outros problemas.

Isso posto, o objetivo deste artigo é investigar as inter-relações entre a política monetária e a dívida pública brasileira entre 1999 e 2016. Embora seja um período longo e heterogêneo, a escolha se justifica por comportar a fase posterior à adoção da estratégia do RMI, que trouxe implicações relevantes para a condução das políticas macroeconômicas domésticas, não somente a monetária, mas também a fiscal e cambial.

Para alcançar o objetivo a que se propõe, este artigo está dividido em cinco seções, incluindo esta introdução e as considerações finais. Na seção 1 é apresentada a retomada histórica do surgimento da dívida pública nos anos 1960 até a introdução do RMI e a política de superávits primários adotados pelo governo brasileiro em 1999. Na seção 2 são analisados os dados da economia brasileira no período de 1999 a 2016, que permitem a observação de problemas com os mecanismos de transmissão da política monetária, a inter-relação entre duas políticas (monetária e fiscal), que são formuladas por agentes independentes, a falta de coordenação entre estes e, consequentemente, a perda de eficácia de ambas as políticas. Em seguida, na seção 3, são mencionados aspectos como o prazo de rolagem da dívida pública e sua Duration, essencialmente de curto prazo, que afetam a política fiscal e monetária. Por fim, conclui a análise, enfatizando que a diversidade de objetivos entre as políticas, a falta de sincronia entre elas, os problemas no mecanismo de transmissão da política monetária, implicam em perda de eficácia e em custos para economia, apontando para a necessidade da desvinculação da política fiscal e monetária, a elevação do prazo e duração da dívida pública, mudança da composição dessa e redução da taxa Selic.

\section{As instituições para a gestão da dívida pública no Brasil}

\subsection{Das reformas do PAEG aos anos 1990: origens e anomalias}

A compreensão acerca da relação existente entre a política monetária e a dívida pública no Brasil remonta ao surgimento do mercado da dívida pública no país nos anos 1960, bem como das instituições que foram criadas para a sua gestão naquele contexto.

No início dos anos 1960, o país vivenciava uma grave crise política e econômica, com baixo crescimento do PIB e aceleração inflacionária, cenário que conduziu ao golpe militar de 1964 e impôs diversas mudanças institucionais, particularmente, por meio do Plano de Ação Econômica do Governo (PAEG), destacando-se a reforma tributária ${ }^{6}$ e monetário-financeira.

(3) A discussão acerca das medidas adotadas pela reforma tributária, neste período, se encontra além do escopo deste trabalho, todavia, maiores detalhes podem ser obtidos em Abreu (1992) e Hermann (2016). 
As medidas tomadas pela reforma monetário-financeira de 1964 tinham como objetivos centrais possibilitar a convivência com uma inflação moderada, ao mesmo tempo em que constituía um mercado para a dívida pública e de crédito no país. Dentre as mais relevantes, vale notar: i) a instituição da correção monetária, que ao proteger os agentes dos impactos negativos da inflação, traz estímulo à poupança; ii) criação das Obrigações Reajustáveis do Tesouro Nacional (ORTN), que por determinar o índice de correção monetária, contribuíram para fomentar o incipiente mercado de títulos para a dívida pública federal ${ }^{4}$; iii) criação do Conselho Monetário Nacional (CMN) e do Banco Central do Brasil, para conferir independência à política monetária, sendo este último o responsável por realizar operações de compra e venda de títulos públicos federais; iv) reforma do mercado de capitais, dada pela lei n. 4.728 .

O crescimento do mercado de capitais brasileiro, todavia, se intensificou a partir da criação das Letras do Tesouro Nacional (LTN), pelo decreto-lei 1.079, em 21 de janeiro de 1970. Os prazos destes papéis eram, inicialmente, de 42 dias e, posteriormente, 91 e 182 dias. "Em um curto espaço de tempo, as LTNs conquistaram um alto grau de negociabilidade, resultaram no crescimento substancial da participação destes títulos, que atingiram em 1975 mais de 70\% do total da dívida pública brasileira" (Parreiras, 2007, p. 11). Em razão do aumento do volume das operações de mercado aberto brasileiro, foi instituído, pela circular de 11 de outubro de 1979, o Sistema Especial de Liquidação e Custódia (Selic), pelo qual as operações financeiras passaram a ser escriturais e, a liquidação destas, via reservas bancárias das instituições junto ao Banco Central (BC). Estas movimentações eram diárias, ocorrendo via débito e crédito nas contas de reservas bancárias que as instituições mantinham no BC.

Segundo Parreiras (2007), os títulos públicos tornaram-se substitutos quase perfeitos das reservas bancárias. O BC passou a intervir diariamente neste mercado de reservas para definir a taxa Selic, a nova taxa básica de juros da economia brasileira. Assim, as reservas poderiam ser aplicadas em títulos públicos com rendimento diário, financiando a dívida pública.

Isso significava que a taxa de juros que remunerava as sobras de caixa dos bancos nas operações de mercado aberto passou a remunerar também os títulos públicos de longo prazo. Assim, a demanda por reservas excedentes tornou-se independente da taxa de juros, já que nenhum banco deixaria de aplicar suas reservas em títulos públicos, isto é, houve a "fusão" do mercado da dívida pública com o mercado de reservas bancárias, configurando-se a estrutura "anômala" da gestão institucional da dívida pública no Brasil (Parreiras, 2007, p. 13).

Novamente em 1986, no contexto de elevada inflação e da adoção do Plano Cruzado, surgem as Letras do Banco Central (LBC). O objetivo era reduzir o custo da rolagem da dívida pública, todavia, sem impor perdas aos grandes detentores de títulos, na época, primordialmente as instituições financeiras. A inovação foi a criação de um título indexado ao

(4) As emissões das ORTNs, após alcançarem Cr\$ 41 milhões em 1964, totalizaram Cr\$ 5 bilhões em 1969 (Araújo, 2002, p. 10-11). 
overnight e sem risco de taxa. Assim, com a emissão de um título remunerado pela taxa de juros fixada pelo BC e com "recontratação diária", evitou-se o risco de uma crise sistêmica (Amaral; Oreiro, 2008, p. 494).

Mais tarde, com a aprovação da Constituição Federal de 1988, foi proibido o financiamento direto e indireto do BC à União. A partir de então, as LBCs tornaram-se as Letras Financeiras do Tesouro Nacional (LFTs), e o artigo 164 alterou o papel do BC, possibilitando a este afetar a política monetária por meio de operações no mercado aberto, via títulos do Tesouro Nacional. Deste modo, os títulos do tesouro tornaram-se um instrumento de política monetária, ao mesmo tempo em que cumpriam sua função de financiamento da dívida pública.

Os lançamentos e resgates de títulos pelo Tesouro Nacional ocorreriam em função dos fluxos de caixa aprovados pela Lei de Diretrizes Orçamentárias (LDO), por meio de leilões de oferta pública realizados pelo BC. Já no mercado secundário, o BC recompraria os papéis à taxa Over Selic. Como não há limites quantitativos de emissões e compra desses papéis, não há disputa concorrencial dos mesmos que poderia alterar seus preços (Marques, 1997).

Vale notar ainda, que o artigo 165 da CF/1988 regulamentou a criação de uma Conta Única do Tesouro. Nesta, seriam registrados separadamente os recursos de origem tributária (destinados a suprir as demandas das unidades gestoras da administração federal) e não tributária (rolagem da dívida interna, operações com certificados de privatização, liberações de recursos e pagamento de empréstimos externos, remuneração do Banco Central a essa Conta do Tesouro, feita decendialmente, à taxa Over Selic, assim como os resultados contábeis positivos transferidos pelo BC, também decendialmente, ao Tesouro) (Marques, 1997).

Assim, o BC auferia ganhos de senhoriagem (poder de compra pela diferença entre a emissão de base monetária e o custo de impressão da moeda fiduciária) e receita do imposto inflacionário (emissão de base monetária além do crescimento de preços). Como se sabe, grande parte do resultado do BC decorre do poder de emitir papel-moeda e de impor compulsórios sobre os depósitos à vista, já que estes recursos não têm qualquer custo financeiro para o BC. Ademais, existiam possibilidades de ganhos com a realização de operações de mercado aberto e das operações cambiais, compras e vendas de títulos e de dólares, respectivamente.

Essas duas anomalias - a remuneração da conta do tesouro e a transferência do resultado contábil positivo do $\mathrm{BC}$ ao $\mathrm{TN}$ - são subprodutos da engenharia financeira do governo, após a determinação constitucional da existência dessa conta. Desse modo, a administração monetária se interliga à administração da dívida pública: ao determinar a Selic no open Market, o BC precisa analisar o impacto no estoque de títulos públicos, dado que os efeitos desta política sobre a dívida pública impactaram sobre os resultados da política monetária (Amaral; Oreiro, 2008). 
Novas mudanças ocorreram por ocasião da implementação do Plano Verão, em 1989. As OTNs foram trocadas pelas LFTs e surgiram os Bônus do Tesouro Nacional (BTNs), títulos que eram atualizados pelo Índice de Preços ao Consumidor (IPC). E também no governo Collor (1990-92) que, na tentativa de conter o custo crescente da dívida, permitiu que o BC emitisse títulos de sua responsabilidade - os Bônus do Banco Central (BBC) - o que elevou a participação destes no montante da Dívida Pública Mobiliária Federal Interna (DPMFi). Além disso, foi introduzido outro papel, as Notas do Tesouro Nacional (NTN), que continuam vigentes até os dias atuais e possuem várias séries, denominadas por letras, cada uma com um diferente indexador, sendo os principais a taxa de câmbio, os índices de preços, além das préfixadas e de uma pequena parcela indexada à Taxa Referencial (TR) (Parreiras, 2007, p. 19).

Todas essas instituições, desde a década de 1960 até a década de 1990, permitiram a convivência com a inflação, evitando-se a total rejeição da moeda pelo público, em particular, em momentos que esta atingia patamares críticos. Além disso, serviram ao propósito de viabilizar o financiamento do governo, via títulos públicos, além de um papel importante na evolução do mercado aberto no país e na criação de fundos para aplicação financeira por parte dos bancos e outras instituições, num contexto de elevada inflação.

Desde os anos 1990, a economia brasileira passou por consideráveis mudanças, com destaque para a estabilização inflacionária em 1994 e abertura comercial e financeira. A despeito disso, a vinculação entre a política monetária e a dívida pública permaneceu complexa e problemática, uma vez que diversos expedientes utilizados por ocasião do passado inflacionário continuam inalterados.

\subsection{O regime de metas para inflação (1999) e a política de superávits primários}

Com a implantação do Plano Real em meados de 1994, a estabilidade de preços tornouse uma realidade no país, que durante quase duas décadas convivera com um longo e doloroso processo inflacionário.

A partir de então, a política monetária direcionou-se para a sustentação da estabilidade de preços, inicialmente via adoção de âncoras monetária e cambial. Após 1999, dada a impossibilidade de manutenção das âncoras mencionadas e a mudança para o regime de câmbio flutuante em 1999, foi introduzido o Regime de Metas de Inflação (RMI), em julho do referido ano ${ }^{5}$.

Um dos fundamentos conceituais do RMI é a regra de Taylor, baseada no modelo teórico proposto por Taylor (1993), ao postular que a taxa de juros se relaciona positivamente com o hiato do produto e com o desvio da inflação de uma determinada meta. A autoridade

(5) O RMI passou a ser adotado por vários países a partir dos anos 1990. Entre estes estão Austrália, Nova Zelândia, Canadá, Inglaterra, Suécia. Nos Estados Unidos, o RMI está implícito na conduta da política, mas não é adotado formalmente. Para mais detalhes ver Arestis et al. (2009). 
monetária, nesse sentido, deve atuar na determinação da taxa de juros básica da economia em resposta a essas variações, segundo uma espécie de "função de reação".

No caso brasileiro, compete ao BC monitorar o índice de preços, IPCA, para que a inflação não desvie da meta proposta pela autoridade monetária, anunciada pelo Conselho Monetário Nacional (CMN), formado pelo ministro da Fazenda, ministro do Planejamento e o presidente do BC.

A responsabilidade pelo cumprimento das metas estabelecidas é do $\mathrm{BC}$, que deve ajustar a taxa de juros básica da economia nominal à média da taxa Selic, estabelecida pelo Copom. O ajuste é realizado por operações de compra e venda de títulos remunerados pela taxa Selic. Quando há elevação, mesmo que sazonal, da taxa de inflação, o BC eleva a taxa Selic para conter a demanda, e com isso reajustar a inflação à meta estabelecida. A determinação da taxa Selic ocorre em reuniões periódicas do Copom, tendo como membros a diretoria do BC (Couto et. al., 2010).

Vale notar que, no Brasil, o único objetivo a ser perseguido pela política monetária é o controle inflacionário. Diferentemente da política monetária, o objetivo da política fiscal brasileira é a manutenção de superávits primários. O superávit primário (diferença entre as receitas do governo central, regional e empresas estatais e suas despesas correntes e de investimento, excluindo suas despesas financeiras), é uma política adotada pelo governo para sinalizar aos agentes sua capacidade de pagamento dos juros da dívida pública garantindo a credibilidade das políticas macroeconômicas, tanto monetária, fiscal, cambial, entre outras.

Além de impactar nas expectativas dos agentes da economia, o cumprimento das metas de superávits é importante por ser observado na avaliação do risco-país, que impacta na formação da taxa de juros para atração de capital externo, bem como na taxa de câmbio.

A tarefa que lhe cabe é servir de pilar de sustentação e farol do comportamento esperado de outras variáveis macroeconômicas. Não se trata apenas de relembrar a discussão tradicional do déficit público e as implicações sobre inflação, déficit externo e o crowding out. O resultado das contas públicas passou a ser visto como o indicador central usado na orientação dos investidores em suas decisões de investimentos, isto é, as mudanças na percepção da trajetória da situação fiscal servem de sinalização para os agentes reorientarem a composição das aplicações, gerando movimentos de capitais, com repercussões no prêmio de risco, bem como nas taxas de câmbio e de juros dos países vistos como de maior fragilidade. Esta visão reforçou a certeza dos que defendem a ampliação do ajuste fiscal como forma de sustentar às expectativas dos investidores, uma vez que alterações na forma de perceber a trajetória da política fiscal servem ao questionamento de outras variáveis e impulsionam o risco de crise financeira (Lopreato, 2006, p. 8)

(6) O RMI é considerado o "estado das artes" pelo Novo Consenso Macroeconômico (NCM). Postula-se que a inflação deve ser baixa e estável para o crescimento de longo prazo; apoia-se em elementos teóricos e empíricos de diversas vertentes de pensamento, tais como a hipótese das expectativas racionais e a inconsistência temporal da política monetária ou viés inflacionário (escola novo-clássica); assim como, traz implícitas ideias antigas na macroeconomia, como da taxa natural de desemprego e a neutralidade da moeda no longo prazo (clássicos e monetaristas). Confira Arestis e Sawyer (2008). 
É importante mencionar que a adoção de metas de superávit primário no Brasil data do ano de 1998, quando num cenário de graves desequilíbrios internos e externos, o governo fez um acordo com o Fundo Monetário Internacional (FMI), Banco Mundial e BIS (Bank for International Settlements), para a obtenção de um empréstimo de US\$ 41 bilhões. A contrapartida foi o atendimento a uma série de exigências, dentre elas o equilíbrio das contas públicas, estabelecendo para o ano de 1999 um superávit primário de 3,1\% do PIB.

A manutenção dos superávits primários é considerada, por muitos estudiosos, importante para a estabilidade das economias, pelo impacto exercido sobre as expectativas e ações dos agentes e, portanto, para garantir a efetividade da política monetária. Todavia, sem uma redução de gastos, possibilitada por uma reforma fiscal, a economia pode tornar-se dependente da dívida pública para se autofinanciar.

No caso brasileiro, vale notar que o país não tem enfrentado problemas de financiamento. Conforme Couto e Couto (1999), o crescimento da dívida pública e suas consequências, como a elevação do montante de juros a serem pagos e o superávit primário a ser alcançado, não decorrem de problemas oriundos de gastos acima das receitas e sim de ajustes de liquidez da economia.

A estrutura anômala do endividamento público existente no país demandaria elevados superávits primários para a rolagem total da dívida, pois sem a alteração dos mecanismos criados para a convivência com a inflação, as "sobras de caixa" bancárias ou excesso de liquidez, dinheiro captado pelos bancos não emprestados, são captados pelo BC, por meio da venda de títulos públicos remunerados pela Selic, ajustes de liquidez.

Na raiz deste problema se encontra a cultura do investidor brasileiro que, em momentos de alta da Selic, é considerada como um recurso seguro para investimento e em momentos de alta rentabilidade demandam títulos remunerados por tal taxa para investir seus recursos. Uma vez que uma parcela substancial da dívida é remunerada pela taxa básica de juros da economia (Selic), ao elevar a taxa Selic para conter a inflação, o governo ao mesmo tempo eleva a dívida pública, o que requer o aumento do superávit primário.

É neste sentido que se observa a inadequação da estrutura atual, a qual, embora criada para a convivência com uma inflação elevada, se mantém até os dias atuais, a despeito da drástica redução desta. O mesmo é válido para a política de compra das reservas bancárias com títulos públicos remunerados à taxa Selic.

Num cenário de baixa inflação, mantém-se a interligação espúria da política monetária e endividamento público. Embora, os últimos anos tenham sido caracterizados pela tentativa de alongar o prazo da dívida e introduzir mais títulos pré-fixados, como será evidenciado na próxima seção, nos momentos de crise o BC e TN prezam pela rolagem da dívida via mecanismos criados num contexto de inflação acelerada (Ferreira; Robotton Filho; Dupita, 2004) 


\section{A interconexão entre política monetária e a dívida pública no Brasil (1999-2016)}

Nesta seção tem-se a análise da evolução de variáveis ligadas à política monetária e a dívida pública no Brasil entre 1999 e 2016. Tal análise permite a observação de problemas na inter-relação entre a política monetária e a dívida pública, que reduz a eficácia da referida política.

No Gráfico 1, a seguir, é apresentada a trajetória da taxa Selic no período de janeiro de 1999 a dezembro de 2016, que de forma geral, pode ser analisada segundo três fases distintas. Primeiramente, a taxa básica de juros foi extremamente elevada entre julho de 1999, quando foi implementado o RMI, até por volta do ano de 2005. Nesta fase, é importante destacar os momentos de instabilidade econômica internacional e também nacional, como em 2003, quando tiveram as eleições para presidente, com a ascensão ao poder de um candidato de um partido de esquerda, Luiz Inácio "Lula" da Silva; no segundo semestre de 2004 e durante o ano de 2005, a alta da Selic se deveu à elevação do preço do petróleo no mercado internacional e crescimento da economia.

Gráfico 1

Taxa Selic overnight diária (\% a.a.), no período de 01.1999 a 12.2016

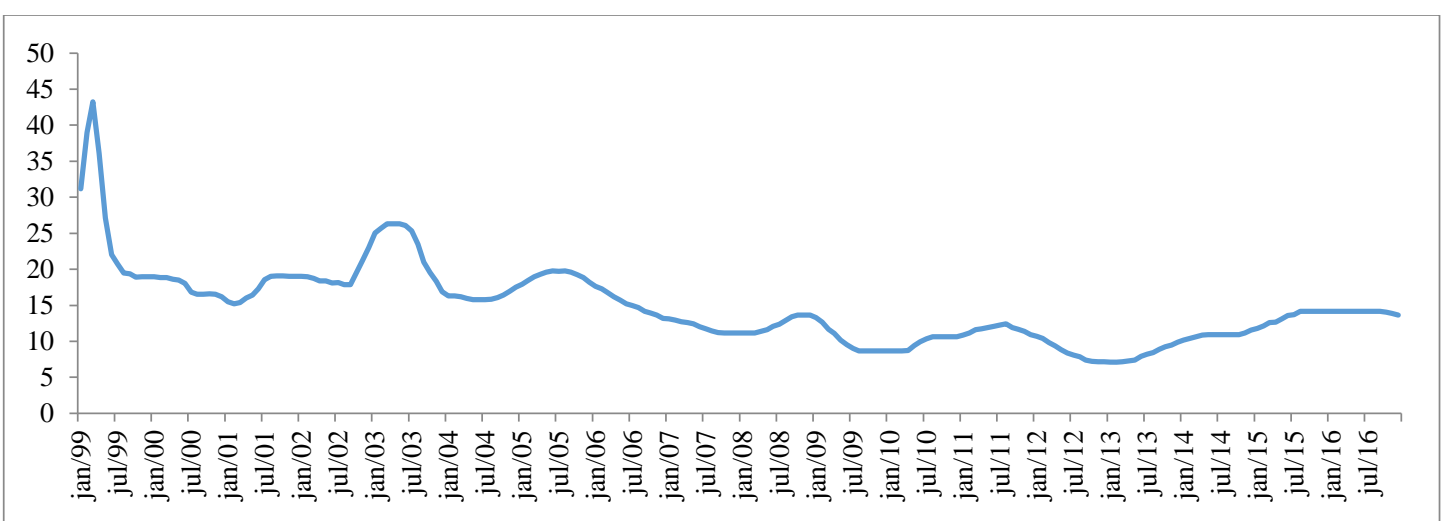

Fonte: Elaboração dos autores a partir de BCB (2017).

Na sequência, tem-se uma trajetória de queda da taxa Selic, a despeito de sobressaltos em alguns anos, no período que compreende de 2006 a 2013. A melhoria do cenário externo, provocada pelo boom dos preços das commodities e a maior liquidez internacional, aliado à expansão do emprego e da renda doméstica, conduziu a uma melhora de fundamentos da economia brasileira, num cenário de inflação controlada, o que possibilitou a queda gradual dos juros. Os sobressaltos em 2008/2009 ocorreram em razão da deflagração da crise do Subprime na economia norte-americana e, no ano de 2011, foram as pressões internas sobre a inflação, que se encontrava acima da meta, que motivaram a alta da taxa Selic.

Importante salientar que, embora em alguns períodos a Selic tenha se mantido elevada, durante o primeiro mandato da presidente Dilma Roussef (2011-2014), a taxa básica de juros 
atingiu o seu limite inferior histórico: 7,25\% a.a, em março de 2013. Esse feito foi possível pela alteração ${ }^{7}$ da condução da política monetária, que passa a dar mais importância aos indicadores de atividade econômica (e não só a inflação), com a decisão daquele governo em manter a taxa Selic baixa para incentivar o crescimento doméstico.

Finalmente, após 2013, inicia-se uma nova trajetória de alta da taxa básica de juros. O cenário de baixo crescimento econômico, aliado à reversão do cenário externo benigno tiveram efeitos negativos sobre as contas públicas. Além disso, em 2014, pressões inflacionárias, em parte justificadas pela elevação de preços administrados, despesas com a Copa do Mundo e por gastos oriundos das eleições, dentre outros, implicaram em elevação inflacionária e a continuidade da alta da taxa Selic, que atingiu $14,25 \%$, quase o dobro do patamar verificado no início de 2013.

Pelo fato de a taxa Selic ser um dos principais indexadores da dívida pública, seu comportamento impactou no montante desta. Como pode ser analisado no Gráfico 2, a Dívida Pública Mobiliária Federal, em proporção do PIB (DPMF), apresentou tendência de crescimento no período analisado. Já a proporção da dívida pública indexada à Selic, que apresentava redução, passou a crescer significativamente a partir de 2015. Em dezembro de 2016, a proporção da DPMF indexada à Selic era de 30,3\%, e o valor dos títulos da dívida indexada à Selic, em proporção do PIB, de 19,5\%.

\section{Gráfico 2}

Dívida pública mobiliária federal (\%PIB) e parcela da dívida indexada à Selic (\% PIB e \% DPMF) no período de 01.1999 a 12.2016

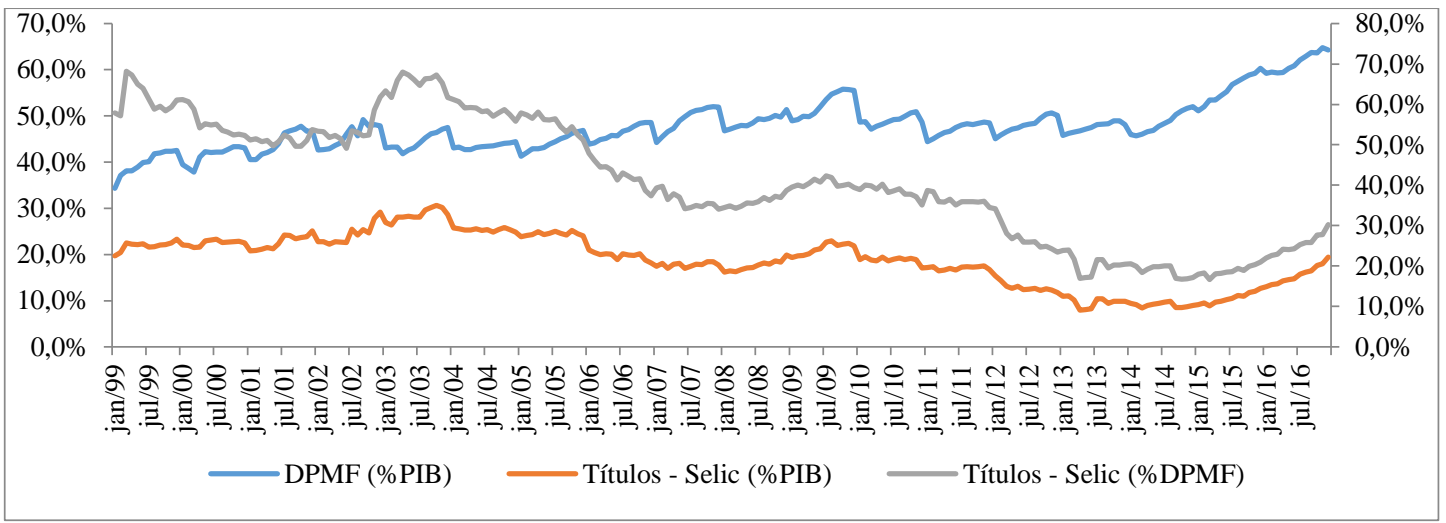

Fonte: Elaboração dos autores a partir de BCB, (2017) e IBGE (2017).

(7) Esta alteração não foi anunciada pelo governo, mas é facilmente percebida ao se contrastar as decisões contidas nas Atas do Copom, que passaram a considerar a atividade econômica também como fator influente na inflação, assim como a taxa de juros, aproximando-se ao modelo adotado pelo BC americano. 
Fica claro, neste sentido, que o problema de parcela da dívida ser indexada à taxa Selic interfere no mecanismo de transmissão da política monetária, de modo que quando a autoridade monetária eleva a Selic para conter a inflação, eleva-se a parcela da dívida pública.

Observa-se também ao se comparar os Gráficos 1 e 2 que o comportamento dos títulos indexados à Selic, em proporção da dívida pública mobiliária federal, apresenta tendência semelhante ao comportamento da taxa Selic: os períodos de queda do percentual da dívida indexada à taxa básica coincidem com períodos em que esta apresentou redução. Isso não denota, contudo, que a substituição dos títulos indexados à Selic, na composição da dívida, possa ser duradoura, pois, de acordo com a tendência de evolução demonstrada nos referidos gráficos, as elevações da Selic são acompanhadas por um aumento da participação de tais títulos na dívida pública.

O perfil da DPMFi é evidenciado no Gráfico 3, a seguir. Observa-se que houve melhoria no perfil de endividamento público, com a redução dos títulos indexados à Selic, principalmente desde 2004, e aumento dos títulos pré-fixados. Outro ponto importante a mencionar, refere-se à queda dos títulos indexados ao câmbio e à elevação dos títulos indexados ao IPCA, que poderia ser um estímulo para o governo manter a inflação em patamares baixos, e, assim, contribuir para não elevar o custo da dívida pública.

Todavia, em momentos de crise, a tendência é que a rolagem da dívida seja realizada com elevação da proporção de títulos indexados à Selic. Conforme mostra o Gráfico 3, após o segundo semestre de 2008 e desde o início do ano de 2015, a proporção da dívida indexada à Selic, que vinha sofrendo redução, apresenta uma trajetória de crescimento. No primeiro período, no contexto internacional, ocorreu a maior crise financeira desde 1929 e, no segundo, uma crise econômica e política no Brasil.

Gráfico 3

Proporção da dívida pública mobiliária federal interna por indexador no período de 01.1999 a 12.2016

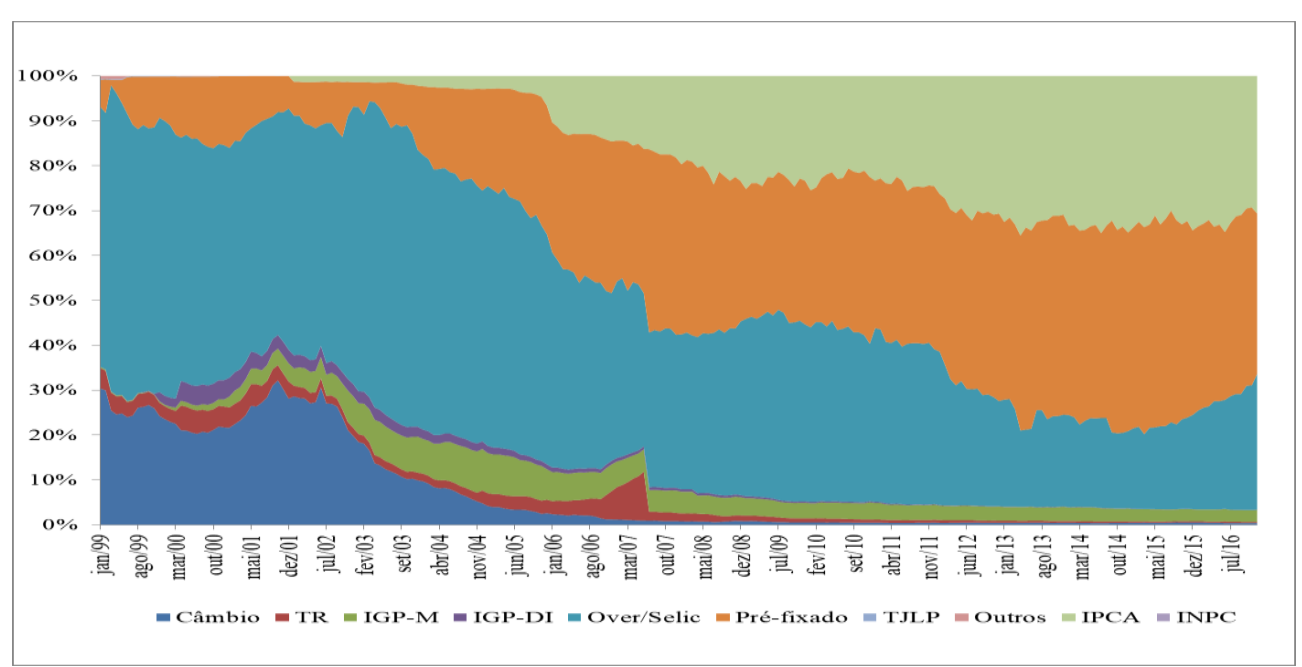

Fonte: Elaboração dos autores a partir de BCB (2017). 
Como já destacado, mais de $30 \%$ da dívida ainda se encontra indexada à Selic; as elevações desta taxa para controle de inflação, responsabilidade do BC, aumentam o custo da dívida, que impacta nos resultados fiscais. Outra desvantagem da dívida indexada à Selic é que tais títulos, ao apresentarem alta liquidez e baixo risco, competem com os investimentos produtivos da economia, ao elevar o custo de oportunidade destes.

O superávit primário (diferença entre as receitas do governo central, regional e empresas estatais e suas despesas correntes e de investimento, excluindo suas despesas financeiras), os juros (que são as despesas financeiras com dívida dos governos central, estaduais e municipais) e o resultado nominal (que se refere ao resultado final do setor público, incluindo as despesas com juros) brasileiros para o período analisado são apresentados no Gráfico 4.

É possível observar, no Gráfico 4, que o governo tem perseguido superávits primários acima dos $3 \%$, os quais não foram obtidos em 2009, devido à crise financeira internacional, e também, entre os anos de 2010 a 2013, quando se situaram entre 1,7 e 2,9\% do PIB. Nos anos recentes, entre 2014 e 2016, os superávits primários se converteram em déficits, refletindo a grave crise econômica e política, em evolução nesta fase.

Gráfico 4

Resultado primário, juros e resultado nominal no setor público consolidado acumulado nos 12 meses (\% PIB) no período de 1999 a 2016

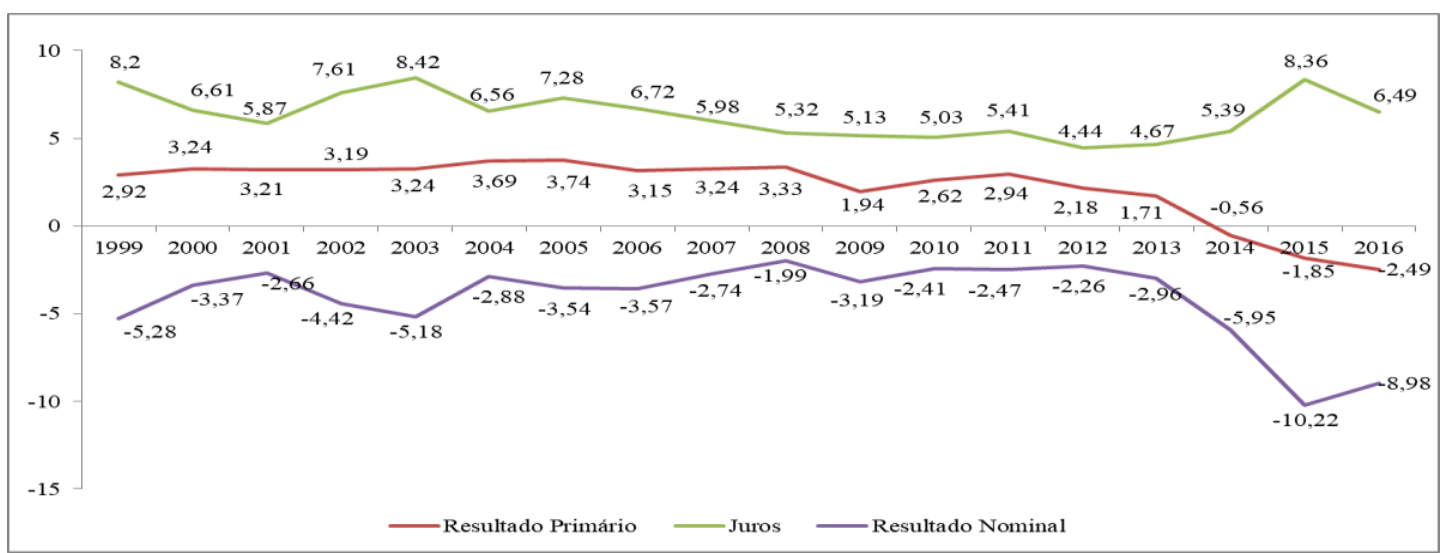

Fonte: Elaboração dos autores a partir de BCB (2017).

Nota-se, a despeito dos esforços para se manter superávits primários elevados, que estes não foram suficientes para cobrir os juros nominais do período, fazendo com que o governo apresentasse déficits nominais em todos os anos estudados. Apesar destes déficits terem se reduzido desde 2005, não de forma contínua - em razão tanto da diminuição da taxa Selic quanto da parcela da dívida pública indexada a ela -, essa redução não foi sustentável e, a partir de 2013, esses déficits apresentaram crescimento pela retomada de crescimento dos juros da dívida e da redução do superávit primário. 
Prosseguindo na análise, na Tabela 1 são apresentadas as metas e a inflação efetiva de 1999 a 2016. Conforme pode ser observado na referida tabela, foram poucos anos em que a inflação situou-se abaixo ou no centro da meta estipulada, permanecendo, na maior parte do tempo, próxima do limite superior da meta ou mesmo ultrapassando-a em alguns anos.

Tabela 1

Metas e inflação efetiva no período de 1999 a 2016

\begin{tabular}{c|c|c|c}
\hline Período & $\begin{array}{c}\text { Meta para inflação } \\
(\%)\end{array}$ & $\begin{array}{c}\text { Limites inferior e } \\
\text { superior }(\%)\end{array}$ & IPCA (\% a.a.) \\
\hline 1999 & 8 & 6 a 10 & 8,94 \\
\hline 2000 & 6 & 4 a 8 & 5,97 \\
\hline 2001 & 4 & 2 a 6 & 7,67 \\
\hline 2002 & 3,5 & 1,5 a 5,5 & 12,53 \\
\hline 2003 & $8,5^{*}$ & & 9,30 \\
\hline 2004 & $5,5^{*}$ & 3 a 8 & 7,60 \\
\hline 2005 & 4,5 & 2 a 7 & 5,69 \\
\hline 2006 & 4,5 & 2,5 a 6,5 & 3,14 \\
\hline 2007 & 4,5 & 2,5 a 6,5 & 4,46 \\
\hline 2008 & 4,5 & 2,5 a 6,5 & 5,90 \\
\hline 2009 & 4,5 & 2,5 a 6,5 & 4,31 \\
\hline 2010 & 4,5 & 2,5 a 6,5 & 5,91 \\
\hline 2011 & 4,5 & 2,5 a 6,5 & 6,50 \\
\hline 2012 & 4,5 & 2,5 a 6,5 & 5,84 \\
\hline 2013 & 4,5 & 2,5 a 6,5 & 5,91 \\
\hline 2014 & 4,5 & 2,5 a 6,5 & 6,41 \\
\hline 2015 & 4,5 & 2,5 a 6,5 & 10,67 \\
\hline 2016 & 4,5 & 2,5 a 6,5 & 6,29 \\
\hline
\end{tabular}

Nota (*): A Carta Aberta, de 21/01/2003, estabeleceu metas ajustadas de 8,5\% para 2003 sem intervalo de tolerância e de 5,5\% para 2004.

Fonte: Elaboração dos autores a partir de BCB (2017).

Um aspecto adicional a ser considerado, com respeito à condução da política monetária, se refere ao fato de que o instrumento utilizado para o controle de preços altera o diferencial de juros doméstico-internacional interferindo nos fluxos de capitais que ingressam na economia, como é mostrado no Gráfico 5. Nota-se a elevação dos investimentos em carteira, que apresenta comportamento semelhante aos investimentos em títulos, em momentos que a taxa de juros básica encontra-se elevada e a economia brasileira estável. Esse tipo de investimento, como sabido, deixa o país em momentos de instabilidade, contribuindo para a elevação da fragilidade externa da economia. 
A partir de 2006, verifica-se forte ingresso de capitais na economia brasileira, somente interrompido pela crise norte-americana de 2008, retomado a partir de 2009/2010, com nova queda em 2014/2015; esta última explicada pela instabilidade econômica e política da economia brasileira.

Gráfico 5

Fluxos externos (US\$ milhões) no período de 1999 a 2016

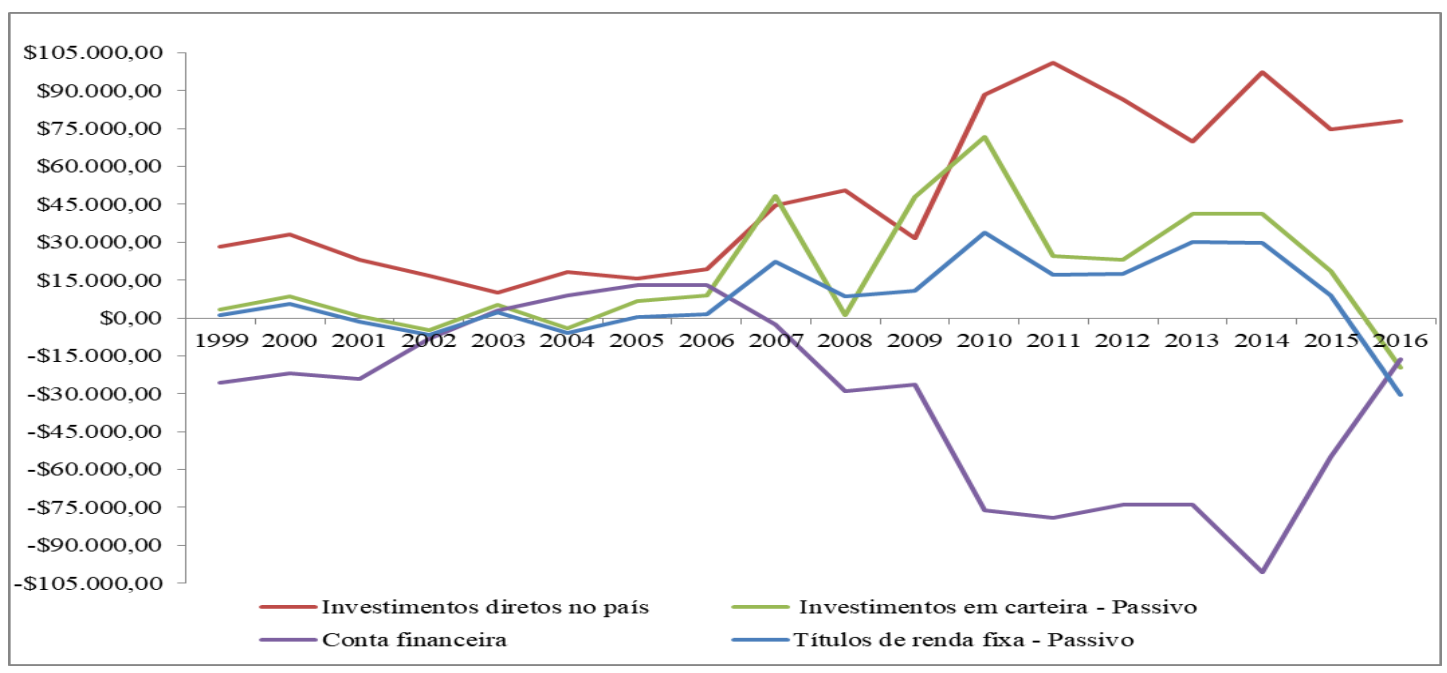

Fonte: Elaboração dos autores a partir de BCB (2017).

Nota-se que os investimentos estrangeiros diretos na economia brasileira apresentam comportamento mais estável do que os investimentos em carteira, além de superarem o montante desses em quase todos os períodos analisados.

Rocha et. al. 2017 (p. 236) destacam que

Desde 2003, o cenário econômico externo favorável, capitaneado pela alta liquidez internacional, juntamente com a melhora dos fundamentos dos mercados emergentes, proporcionou grande entrada de fluxo líquido de capital para os países emergentes, sendo apenas interrompido pela crise das hipotecas americanas em meados de 2007, mas com retomada logo em seguida a partir de 2009 até 2010 . No entanto, entre 2010 e 2015 , houve grande queda dos fluxos de entrada para estes países como um todo, como aponta o relatório do World Economic Outlook (2016). Entre os determinantes dessa queda segundo o relatório, destaca-se principalmente a expectativa de menor crescimento econômico dos emergentes, menores preços de commodities, e a possibilidade do fim do ciclo de política monetária expansiva adotada pelas economias desenvolvidas. A partir de um cenário de menor liquidez internacional aliado ao aumento gradativo da atratividade dos ativos em economias desenvolvidas, os fundamentos de economias emergentes (fatores locais) estão tendo maior importância como direcionadores do fluxo de capital. Economias com fracos fundamentos e maiores vulnerabilidades têm sofrido com menores fluxos de capital, encontrando-se mais expostas ao mercado. 
Um dos problemas ligados ao ingresso destes fluxos externos é que estes têm contribuído para a apreciação cambial, conforme é evidenciado no Gráfico 6. Embora auxiliem no controle inflacionário e no acúmulo de reservas internacionais, os ingressos de fluxos externos implicam em efeito nocivo sobre a redução da competitividade da indústria nacional $^{8}$ e a deterioração dos saldos em transações correntes.

\section{Gráfico 6}

Reservas internacionais (US\$ milhões) e taxa de câmbio (R\$/US\$) no período de 1999 a 2016

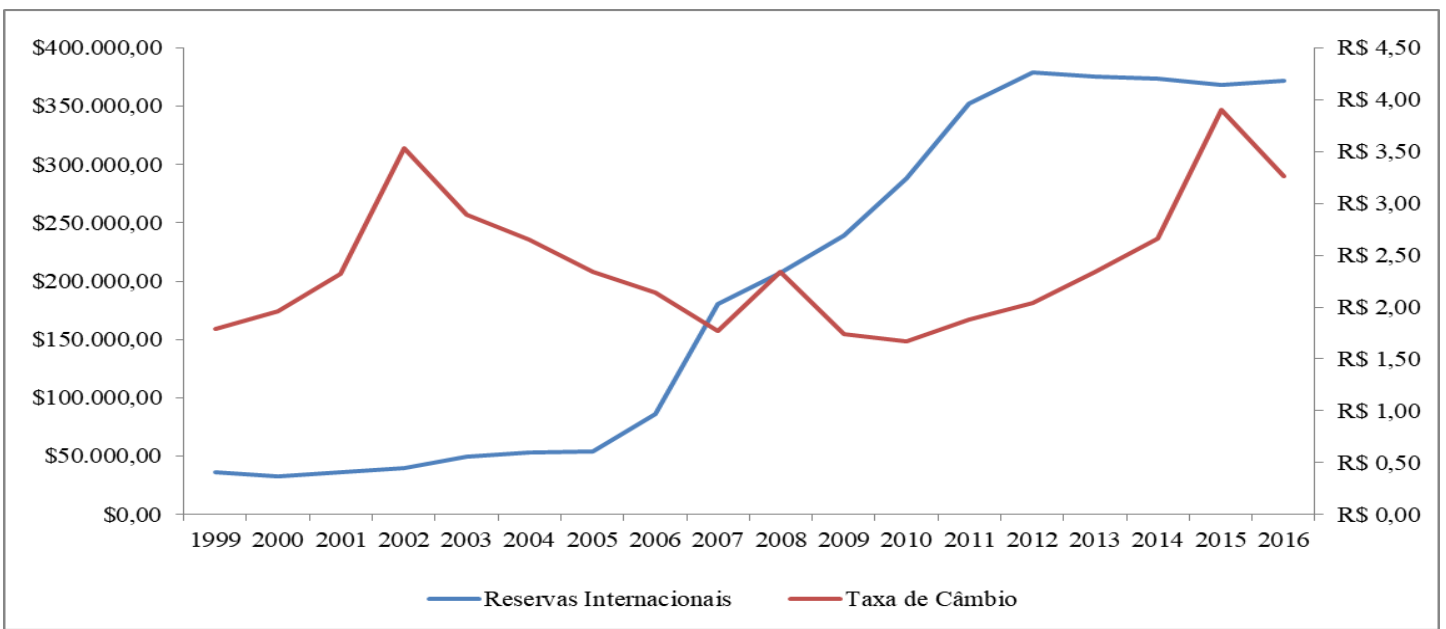

Fonte: Elaboração dos autores a partir de BCB (2017).

Deste modo, a inter-relação entre a política monetária e a dívida pública verificada na economia brasileira não reduz somente a eficácia da política monetária, mas também demanda uma política fiscal mais austera visando maior credibilidade da política macroeconômica. Mas, pelo fato de a taxa Selic elevada impactar em aumento da dívida pública e na redução do prazo desta, esta contribui juntamente com o cenário externo favorável, para a manutenção do câmbio apreciado, que auxilia no controle inflacionário, mas que prejudica o resultado do balanço de pagamento e a competitividade da indústria nacional.

Em suma, a política monetária no Brasil, da forma como tem sido tem conduzida após 1999, tem como principais efeitos a limitada eficácia do RMI; o contágio da dívida pública, cuja parcela representativa é indexada à taxa básica de juros; o ingresso de capitais de curto prazo, que conduzem a uma tendência de apreciação da moeda doméstica; aumentando-se, assim, a vulnerabilidade interna e externa da economia brasileira.

Na próxima seção, são discutidos outros aspectos relativos à dívida pública e de sua conexão com a política monetária, bem como as implicações e problemas daí decorrentes, no período de 1999 a 2016.

(8) Para mais detalhes sobre os efeitos dos fluxos de capitais sobre a taxa de câmbio confira Bresser-Pereira (2009). Sobre a mudança estrutural e a perda de competitividade da indústria brasileira ver Nassif et al. (2013). 


\section{Outras implicações da inter-relação entre a política monetária e a dívida pública: duração e efeito riqueza}

Dentre as características marcantes, a curta duração dos prazos dos títulos da dívida pública surge como um fator que impede a queda mais acentuada da taxa Selic.

O efeito Duration ou a duração do ativo corresponde à variação do preço do título decorrente de mudanças da taxa de juros. Em outras palavras, a duração do ativo é medida pela elasticidade do preço de um ativo, dada uma mudança percentual no fator de desconto deste. Existe, ainda, um segundo conceito de duração relacionando o valor do dinheiro, o tempo, com o prazo médio do título (Amaral; Oreiro, 2008). Pode-se representar a duração do título matematicamente como

$$
D=\frac{\Delta P}{\Delta i} * \frac{(1+i)}{P}
$$
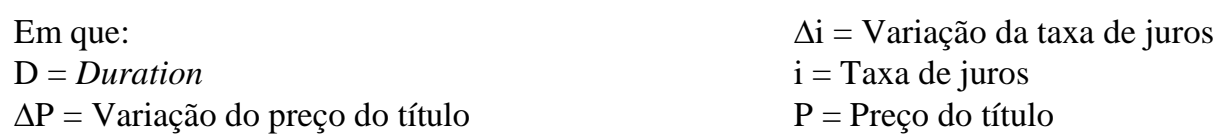

Dada esta definição, pode-se avaliar a situação do Brasil. Como grande parte da dívida pública é indexada à taxa Selic, o valor nominal destes títulos é atualizado diariamente pela taxa básica de juros, de modo que a política monetária não se transmite via "efeito riqueza". Logo, "o tempo necessário para que não haja perdas pelo movimento dos juros (duração) é zero. Como a recontratação é diária, além de não haver perda de capital, o título estará sendo sempre remunerado pela taxa de juros corrente" (Amaral; Oreiro, 2008, p. 497).

O prazo e a duração média da DPMFi estão evidenciados no Gráfico 7; é demonstrado que em janeiro de 1999 o prazo e a duração média correspondiam, aproximadamente, a sete e cinco meses, respectivamente. Estes valores alteraram-se para 52 e 38 meses em dezembro de 2016, uma melhoria clara, porém aquém do necessário e bastante reduzida, se comparado a outras economias desenvolvidas ou até mesmo em desenvolvimento.

Gráfico 7

Prazo e duração média da dívida pública mobiliária federal interna (meses) no período de 01.1999 a 12.2016

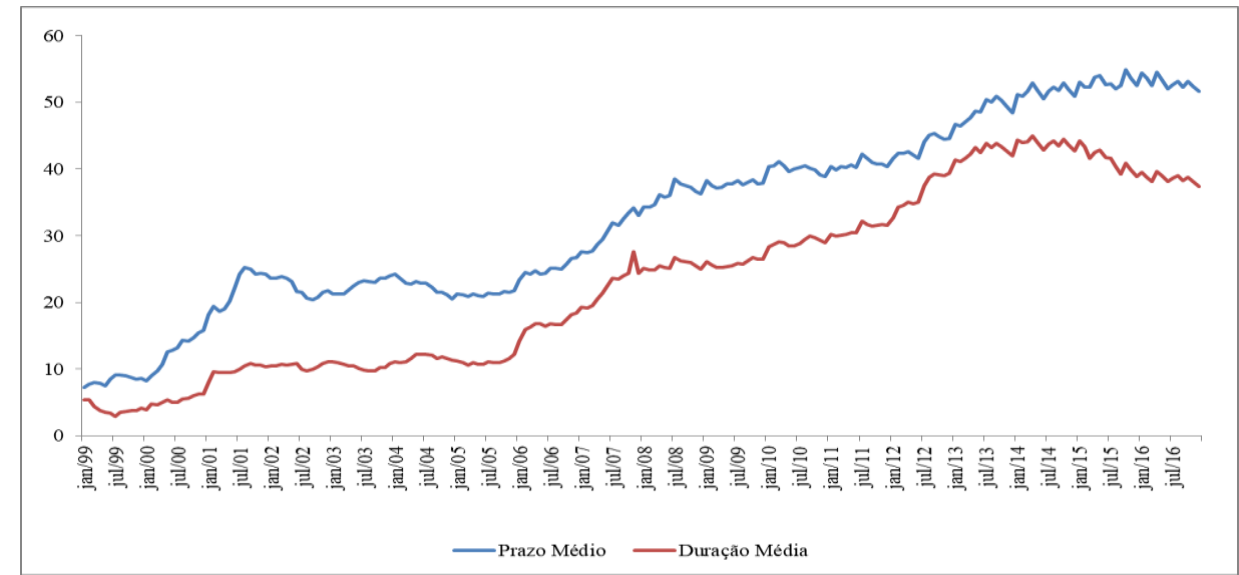

Fonte: Elaboração dos autores a partir de BCB (2017). 
No Gráfico 6 é apresentada a mesma análise do Gráfico 7, porém, de forma desagregada para os principais títulos públicos. São eles

1) Notas do Tesouro Nacional série B (NTN-B), remuneradas pelo Índice de Preços ao Consumidor Amplo (IPCA), acrescidas de juros de 6\% a.a. pagos semestralmente;

2) Notas do Tesouro Nacional série $\mathrm{C}(\mathrm{NTN}-\mathrm{C})$, remuneradas pelo Índice Geral de Preços do Mercado (IGP-M), acrescidas de juros de $6 \%$ a.a. pagos semestralmente;

3) Notas do Tesouro Nacional série D (NTN-D), remuneradas pela desvalorização cambial, acrescidas de juros de $6 \%$ a.a. pagos semestralmente;

4) Notas do Tesouro Nacional série $\mathrm{H}(\mathrm{NTN}-\mathrm{H})$, remuneradas pela Taxa de Referência (TR), com prazos mais curtos que as demais NTN, mas não pagam juros;

5) Notas do Tesouro Nacional série E (NTN-E), remuneradas pela Taxa Básica Financeira (TBF) - só incorporam a variação das taxas de juros uma vez ao mês;

6) Notas do Tesouro Nacional série F (NTN-F), remuneradas pela Taxa Interna de Retorno (TIR) do fluxo de pagamentos dos cupons de juros e do deságio ou ágio sobre o valor nominal do título. Pagamento semestral de cupom de juros de $10 \%$ a.a;

7) Notas do Tesouro Nacional série $\mathrm{S}$ (NTN-S), títulos híbridos, com períodos de remuneração pré e pós-fixados;

8) Letras do Tesouro Nacional (LTN), com rendimentos pré-fixados;

9) Letras Financeiras do Tesouro (LFT), remuneradas pela taxa over Selic.

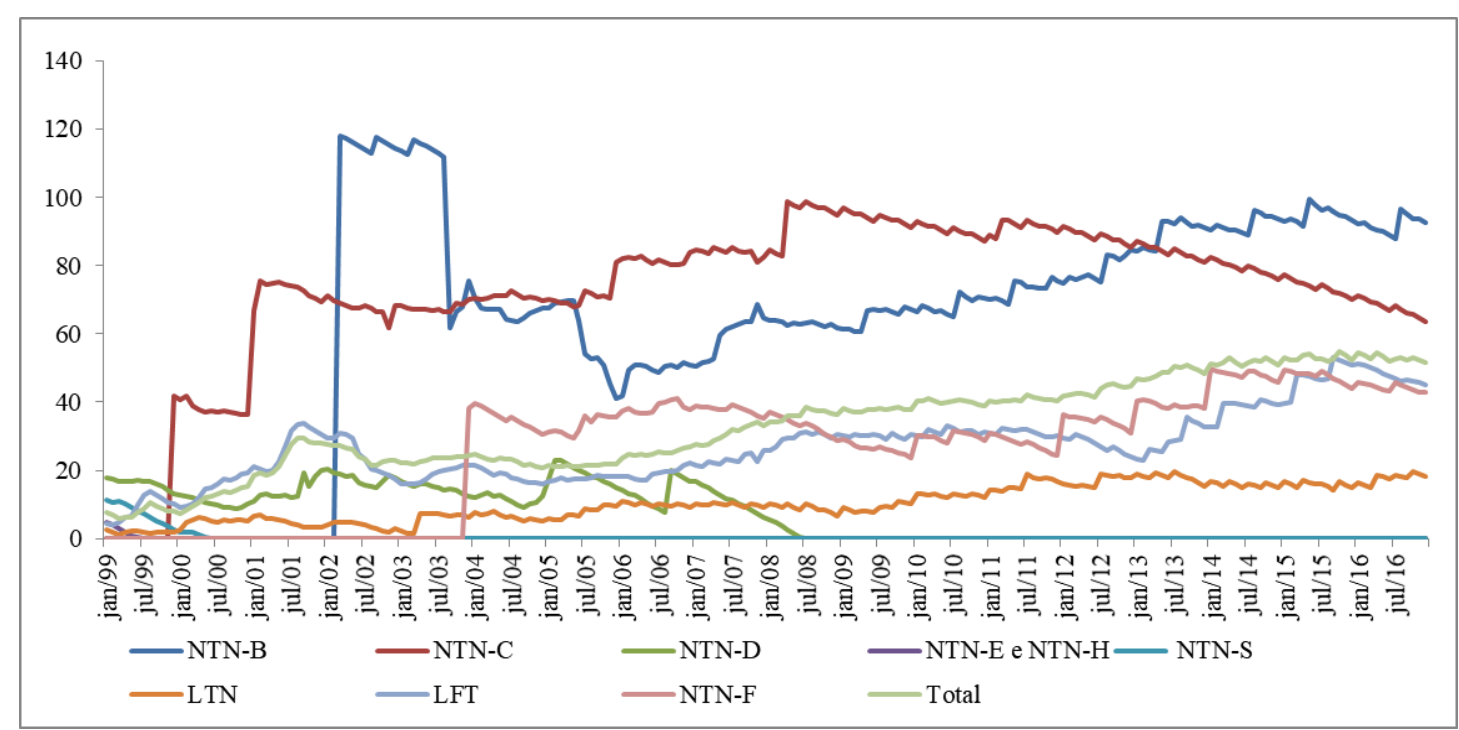

Fonte: Elaboração dos autores a partir de BCB (2017). 
Ao se observar o Gráfico 8, nota-se que o crescimento do prazo e a duração da dívida estão, principalmente, relacionados à elevação destes nos títulos NTN-B e NTN-C, e da elevação destes títulos na composição da dívida substituindo gradativamente as NTNs séries D, E, F, H e S, considerados como pré-fixados.

Nota-se ainda que, embora não seja constante, há a tendência de crescimento do prazo e a duração média da dívida pública - principalmente pelos títulos NTN-B, indexados ao IPCA, que além de demonstrar uma trajetória de elevação do prazo e duration, tem aumentado sua participação na composição da DPMFi - esta destaca-se a partir de meados de 2007 e 2008 , mesmo período em que se observa a redução dos títulos indexados ao overnight. Todavia, os títulos indexados à Selic continuam ainda em uma proporção elevada na composição da dívida pública o que constitui um fator de risco para a dinâmica desta e contribui para baixos patamares de rating e níveis altos de risco-país?.

Um segundo problema que pode implicar em distorção na forma pela qual os mecanismos de transmissão da política monetária afetam a economia é dado pelo denominado "efeito riqueza". O efeito riqueza ocorre quando as elevações da taxa de juros provocam a redução no preço dos ativos, reduzindo a riqueza financeira dos agentes que investem em títulos. Desta forma, estes agentes tendem a diminuir seu consumo, o que auxilia na contração da demanda agregada. A redução da taxa de juros, por outro lado, impacta positivamente na riqueza financeira dos agentes e na demanda agregada.

O funcionamento correto desse canal, contudo, não se verificaria em países onde a taxa de juros básica da economia remunera títulos da dívida pública. A elevação desta taxa levaria à redução da riqueza financeira dos agentes pela perda do valor do ativo, dado que o preço do ativo é igual ao rendimento deste ativo dividido pela taxa de juros $(\mathrm{P}=\mathrm{j} / \mathrm{i})$. Entretanto, quando a taxa de juros definida pela autoridade é a mesma que remunera o título, a redução do preço do título seria compensada pela elevação da remuneração deste, elevando a riqueza financeira dos agentes detentores destes títulos. Esse efeito ficou conhecido como "Efeito Riqueza às Avessas", no qual uma elevação da taxa de juros provoca o aumento da riqueza financeira dos agentes e expansão da demanda por parte destes.

No caso dos títulos indexados à Selic, a duração é 0 , como destacado anteriormente. Essa peculiaridade impacta na economia ao distorcer o efeito riqueza.

Portanto, sendo nula a duração das LFTs, não há a ocorrência do chamado efeito riqueza derivado de elevações da taxa de juros. Ao contrário do que ocorre com os títulos prefixados, por exemplo, em que aumentos da taxa Selic diminuem o preço de mercado do título e, portanto, "tornam os detentores de tais ativos mais pobres", no caso das LFTs esse mecanismo inexiste (Amaral; Oreiro, 2008, p. 498).

(9) Segundo Chrystal et al. (1999) existem dois efeitos pelos quais a dívida pública pode afetar a eficácia da política monetária: i) o efeito na composição do débito, no qual alterações na composição da dívida, quanto à periodicidade e indexação, podem afetar os retornos esperados ativos e dificultar a rolagem da dívida pública e, ii) o efeito da posse da dívida, segundo o qual a emissão de títulos da dívida pública aos bancos reduz a competição destes por emprestadores privados, ou seja, os bancos prefeririam emprestar seus recursos ao governo (via compra de títulos públicos) do que aos demais agentes econômicos. 
A elevação da taxa Selic reduz o preço dos títulos, contudo, como estes são indexados a ela, ao mesmo tempo, aumenta-se a remuneração desses títulos na mesma proporção da redução dos preços, não gerando perdas na riqueza financeira dos agentes detentores.

Embora não existam evidências empíricas claras da existência de um "efeito riqueza às avessas" no Brasil, sendo mais plausível a crença em outros fatores de natureza institucional e estrutural, ele fornece uma explicação interessante acerca do reduzido efeito da política monetária sobre a demanda agregada.

\section{Comentários finais}

Este trabalho discutiu a interligação existente entre as políticas monetária e a dívida pública no Brasil, com foco da análise no período 1999-2016.

Partindo-se de uma discussão sobre o contexto de criação das instituições responsáveis pelo gerenciamento da dívida pública nos anos 1960, observou-se que estas surgiram para atender às necessidades específicas daquele contexto de inflação elevada e inexistência de mecanismos de financiamento, públicos e privados no país. Todavia, mesmo após o controle da inflação em 1994 e a criação de um novo arcabouço para a manutenção da estabilidade macroeconômica, a condução da política monetária continua a afetar o endividamento público.

Em primeiro lugar, através da análise dos dados explorados pela presente pesquisa e da literatura estudada, foi possível verificar que a política monetária impacta diretamente sobre o estoque da dívida pública. Dada a interligação entre as duas principais políticas (monetária e fiscal), dada pela taxa básica de juros (Selic), que ao mesmo tempo é utilizada como instrumento de controle da inflação e como remuneração de uma parcela representativa de títulos da dívida pública - as LFTs, as alterações da referida taxa de juros para fazer frente a aumentos da inflação, por exemplo, provocam a elevação da dívida.

Neste sentido, a despeito da diversidade de objetivos entre as políticas monetária e fiscal - a primeira, que visa a estabilidade de preços, enquanto a segunda se orienta pela busca de superávits primários - a vinculação existente entre as políticas implica em perda de eficácia e em custos para economia como um todo. Vale notar, que não só a eficácia da política monetária é reduzida, mas também uma política fiscal mais austera é requerida para arcar com o crescente pagamento de juros e, desse modo, conferir credibilidade à política econômica. A parte do orçamento público destinada a gastos essenciais, tais como educação, saúde, infraestrutura etc., se torna cada vez mais reduzida, comprometendo o desenvolvimento econômico do país.

Outra consequência da inter-relação destas políticas é a possibilidade de ocorrência de um efeito riqueza às avessas, que poderia explicar parte da redução da eficácia da política monetária. A elevação da taxa Selic reduz o preço dos títulos, porém, uma vez que estes são indexados a ela, ao mesmo tempo, aumenta-se a remuneração desses títulos na mesma proporção da redução dos preços, não gerando perdas na riqueza financeira dos agentes 
detentores, impedindo que a política monetária alcance seu objetivo, qual seja, a redução da inflação, via queda da demanda agregada.

A distorção provocada pela vinculação da política monetária também se reflete sobre o prazo e a duração média dos títulos da dívida pública, que foi de 52 e 38 meses em dezembro de 2016, um prazo considerado curto, além de se constituir em um fator que impede a queda mais acentuada da taxa Selic. Como grande parte da dívida pública é indexada à Selic, o valor nominal destes títulos é atualizado diariamente pela taxa básica de juros, de modo que a política monetária não se transmite via "efeito riqueza".

Finalmente, o principal instrumento de atuação da política monetária traz consequências sobre a vulnerabilidade externa da economia. Mantendo-se a taxa de juros em patamares superiores ao necessário, esta contribui para a tendência de apreciação da taxa de câmbio, fato que auxilia no controle inflacionário, mas que prejudica o resultado do balanço de pagamento e a competitividade da indústria. A partir da discussão evidenciada nesta pesquisa, pode-se verificar que algumas ações poderiam contribuir para a solução desse impasse ao desenvolvimento brasileiro, a saber: a redução da taxa de juros básica, mudanças na condução do RMI, com a identificação dos problemas nos mecanismos de transmissão da política monetária e, particularmente, a adoção de instrumentos que contemplem outros tipos de inflação, que não somente a de demanda, possibilitando a elevação da eficácia desta.

Ademais, a desindexação da dívida à taxa de juros básica, a maior prefixação, o alongamento do prazo e a duração desta, aparecem como aspectos fundamentais para o aumento da eficácia das políticas fiscal e monetária. Essas ações também contribuiriam eliminando o escopo para a ocorrência do "efeito riqueza reverso", potencializando a resposta da inflação aos choques na taxa Selic, com o que seria possível uma melhoria do cenário econômico e dos fundamentos requeridos por uma estratégia de desenvolvimento mais sustentada da economia brasileira, em médio e longo prazo.

\section{Referências bibliográficas}

ABREU, M. P. (Org.). A ordem do progresso: cem anos de política econômica republicana 1889-1989. Rio de Janeiro: Campus, 1992.

AMARAL, R. Q.; OREIRO, J. L. A relação entre o mercado de dívida pública e a política monetária no Brasil. Revista de Economia Contemporânea, Rio de Janeiro, v. 12, n. 3, p. 491517, set./dez. 2008.

ARAÚJO, C. H. V. Mercado de títulos públicos e operações de mercado aberto no Brasil aspectos históricos e operacionais. 2002. (Nota Técnica do Banco Central, n. 12).

ARESTIS, P.; SAWYER, M. New consensus macroeconomics and inflation targeting: a Keynesian critique. Economia e Sociedade, v. 17, número especial, p. 631-655, dez. 2008.

ARESTIS, P.; PAULA, L. F.; FERRARI FILHO, F. A nova política monetária: uma análise do regime de metas de inflação no Brasil. Economia e Sociedade, v. 18, n. 1, p. 1-30, abr. 2009. 
Elohá Cabreira Brito, Eliane Cristina de Araújo, Elisangela Luzia Araujo

BANCO CENTRAL DO BRASIL. Séries Temporais. Disponível em: http://www.bcb.gob.br. Acesso em: 15 out. 2017.

BAER, W. The Brazilian economy: growth \& development. 7. ed. Colorado (USA): Rienner, 2013.

BARBOSA, F. H. The contagion effect of public debt on monetary policy: the Brazilian experience. Revista de Economia Política, v. 26, n. 2, p. 231-238, abr./jun. 2006.

BRESSER-PEREIRA, L. C. A tendência à sobreapreciação da taxa de câmbio. Econômica, Rio de Janeiro, v. 11, n. 1, p. 7-30, jun. 2009.

CARNEIRO, Dionísio Dias; WU, Thomas. A qualidade da dívida pública brasileira. Casa das Garças, 2005. (Texto para Discussão, n. 9).

CHRYSTAL, Alec; HALDANE, Andrew; PROUDMAN, James. Government debt structure and monetary conditions. Bank of England. Quarterly Bulletin, v. 39, n. 4, p. 393-396, 1999.

CONSTITUIÇÃO FEDERAL. São Paulo: Rideel, 1988.

COUTO, A. C. L.; BRITO, E. C.; COUTO, J. M.; SILVA, G. M. O Regime de metas de inflação no Brasil: características e algumas críticas aos seus principais fundamentos. $A$ Economia em Revista - AERE, v. 18, n. 2, p. 85-98, 2010.

COUTO, A. C. L.; COUTO, J. M. A fábula do cavalo morto ou o déficit público do Plano Real. A Economia em Revista - AERE, v. 7, n. 2, p. 129-137, 1999.

FERREIRA, C. K. L.; ROBOTTON FILHO, M.; DUPITA, A. B. Política monetária e alongamento da dívida pública: uma proposta para discussão. PUC-USP, 2004. (Texto para Discussão, n. 09).

HERMANN, J. Reformas, endividamento externo e o "milagre" econômico (1964-1973). In: GIAMBIAGGI, F. et al. Economia brasileira contemporânea (1945-2015). 3. ed. Rio de Janeiro: Campus Elsevier, 2016.

IBGE. Contas Nacionais. Disponível em: http://www.ibge.gov.br/home/estatistica/ indicadores/pib/defaultcnt.shtm. Acesso em: 20 dez. 2017.

LOPREATO, F. L. C. O papel da política fiscal: um exame da visão convencional. Campinas: IE/Unicamp, fev. 2006. (Texto para Discussão, n. 119).

MARQUES, J. A experiência brasileira no manejo da política monetária para a subsistência do mercado da dívida pública, com a despoupança do setor público. II Prêmio STN de monografias, 1997. Disponível em: <http://www.tesouro.fazenda.gov.br/Premio_TN/ IIpremio/divida/1afdpIVPTN/MARQUES Newton_Ferreira.pdf>. Acesso em: 30 set. 2012.

MODENESI, A. M. Convenção e rigidez na política monetária: uma estimativa da função de reação do BCB - 2000-2007. Rio de Janeiro: Ipea, ago. 2008. (Texto para Discussão, n. 1351). 
NASSIF, A.; FEIJÓ, C.; ARAUJO, E. Structural change and economic development: is Brazil catching up or falling behind? United Nations Conference on Trade And Development, Oct. 2013. (Discussion Papers, n. 211). Disponível em: https://unctad.org/en/PublicationsLibrary/ osgdp20131_en.pdf. Acesso em: 31 out. 2017.

PARREIRAS, M. A. A estrutura institucional da dívida pública brasileira e seus impactos sobre a gestão da política monetária: uma análise empírica do regime de metas para a inflação. 2007. Dissertação (Mestrado)-Programa de Pós-Graduação em Economia, Faculdade de Economia, Administração e Contabilidade, Universidade de São Paulo. São Paulo, 2007.

PIRES, M. C. C. Interação entre política monetária e fiscal no Brasil em modelos robustos a pequenas amostras. 2008. Tese (Doutorado)-Programa de Pós-Graduação em Economia, Universidade de Brasília. Brasília, 2008.

ROCHA, K.; MOREIRA, A.; SILVEIRA, M. O fluxo de capital para as economias emergentes e o grau de desenvolvimento do sistema financeiro. Estudos Econômicos, São Paulo, v. 47, n. 02, p. 235-257, abr./jun. 2017.

TAYLOR, J. B. Discretion versus policy rules in practice. Carnegie-Rochester Conference Series on Public Policy, v. 39, p. 195-214, 1993. 